\title{
Evsel Atıklarda Geri Dönüşüm Farkındalığı ve Ekonomiye Katkısının İncelenmesi
}

DOI: $10.26466 /$ opus.689183

\author{
*

\begin{abstract}
Ahmet Alper Sayın*- Asli Yerli **
* Dr.Öğr.Üyesi, Karamanoğlu Mehmetbey Üni./Uygulamalı Bilimler Y.O, Karaman/Türkiye E-Posta: ahmetalpersayin@kmu.edu.tr ORCID: 0000-0002-2086-6763

** Y.L Öğrencisi, Karamanoğlu Mehmetbey Üniversitesi /Sosyal Bilimler Enst., Karaman/Türkiye E-Posta: aslimbozdogan@gmail.com

ORCID: $\underline{0000-0002-4886-0566}$
\end{abstract}

\section{Öz}

Bu araştırmanın amacı günümüzde önemli bir yeri olan evsel atıklarda hane halklarının farkındalığının ölçülmesi ve atıkların çevreye etkisi ile ekonomiye olan katkılarını ortaya çıkarmaktır. Çalışmada, cinsiyet, yaş, medeni hal, eğitim düzeyi gibi demografik özelliklerin evsel atıklar üzerindeki etkisi incelenmiştir. Araştırmada elde edilen verilere, iki bölümden oluşan soru formu aracıllğ̆ ulaşılmıştır. İlk bölümde, demografik özelliklerinin tespit edilmesine yönelik 6 adet sorudan oluşan kişisel bilgi formu yer almaktadır. İkinci bölümde ise bireylerin çevre tutumunu belirlemeye yönelik 16 adet sorudan oluşan çevresel bilincin ölçülmesine ait bilgi formu bulunmaktadır. Çalışma, Eylül ve Aralık 2019 tarihleri arasında Karaman ili temel alınarak, hane bireyleriyle yüz yüze ve telefonda görüşme yapılarak hazırlanmıştır. Örneklem grubu, 124'ü kadın 81' i erkek toplam 210 kişiden oluşmaktadır. Araştırma sonucunda hane halklarının çevre bilinci farkındalığının; cinsiyet, yaş, çalışma durumu, medeni hal, eğitim gibi kriterlere göre değişkenlik gösterdiği tespit edilmiştir. Çalışma da bazı kısıtlılıklar söz konusu olmuş, elde edilen bulgulara göre çeşitli önerilerde bulunulmuştur.

Anahtar Kelimeler: Geri dönüşüm, Tersine lojistik, Evsel atık 


\title{
Recycling Awareness in Domestic Waste and Investigation of Its Contribution to the Economy
}

\begin{abstract}
The purpose of this research is to measure the awareness of households in domestic wastes, which have an important place today, and to reveal the effects of wastes on the environment and their contribution to the economy. In the study, the effect of demographic characteristics such as gender, age, marital status, education level on domestic waste was investigated. The data obtained in the research were accessed through a questionnaire consisting of two parts. In the first part, there is a personal information form consisting of 6 questions for determining the demographic characteristics. In the second part, there is an information form for measuring environmental consciousness consisting of 16 questions to determine the environmental attitude of individuals. The study was prepared between September and December 2019 based on the province of Karaman, by interviewing household members face-to-face and on the phone. The sample group consists of 210 people, of which 124 are women and 81 are men. As a result of the research, environmental awareness of households; It has been determined that it varies according to criteria such as gender, age, employment status, marital status, education. There were some limitations in the study, and various suggestions were made according to the findings.
\end{abstract}

Keywords: Recycling, Reverse logistics, Domestic waste 


\section{Giriş}

Dünya nüfusunun artmasıyla birlikte son zamanlarda atıkların sebep olduğu problemler, önemli çevre sorunlarından biri haline gelmiştir. Artan nüfusla birlikte küreselleşen dünyada kullanım ömrü sona ermiş atıkların geri dönüşümü konusuna, atıkların çevreye ve ekonomiye olan zararlarını minimum düzeye indirilmek istenmesinden dolayı gün geçtikçe ilgi artmaktadır. Artan bu ilgi neticesinde, işletmeler ve hükümetler atıkların geri dönüşüm faaliyetlerine önem vererek, uzun vadede verimli ve karlı bir ekonomik dönüşüm olması için yatırım yapmaya yönelmektedirler. Günümüzde, her geçen gün artarak karşımıza çıkan atıkların durumu, ülkeler açısındanda ciddi sorunlar oluşturmaktadır. Bunun neticesinde, hammadde israfının önlenmesi, atıkların geri kazandırılması, ortaya çıkabilecek enerji sorunlarıyla baş edebilmek için yöntemler aranarak hedefler ortaya konulmaktadır. Atıkların artmasıyla beraber meydana gelen ekonomik ve çevresel bozulmalar ile sürekli gelişen tüketim alışkanlıkları sonucu hammaddenin hızla tükenmesi sorunları, tersine lojistiğe verilen önemin artmasında kaçınılmaz bir rol oynamaktadır.

TUIK istatistiklerine göre kişi başı ortalama atık miktarı $1.16 \mathrm{~kg}$ oranındadır. Aynı zamanda 2018 yılında üç büyük şehirde ise toplanan kişi başı günlük ortalama atık miktarı; İstanbul'da 1,28 kg, Ankara' da 1,18 kg ve İzmir'de 1,36 kg olarak tespit edilmiştir (TUIKK, 2018) Bu rakamlar, hızla artan nüfusun tüketim ihtiyaçlarını karşılamada, düşük maliyet ile maksimum çıktıyı elde edilebilmesi için çevrenin korunarak sürdürülebilir gelişmeyi sağlanmasının önemini göstermektedir. Çevreye ve ekonomiye katkı olmasının yolu, atıkların nihai tüketiciden alınarak üretimin başladığı noktaya doğru akışının sağlanması olarak tanımlanan tersine lojistik ile mümkün olmaktadır.

Literatürde tersine lojistik kavramının birden fazla tanımı bulunmaktadır. Tersine lojistik: tüketici tarafından kullanım ömrü tüketilmiş ve ihtiyaç olmaktan çıkmış, atık haline gelmiş ürünlerin tekrar kullanılabilecek hale getirilmesine kadar meydana gelen lojistik faaliyetlerin tümünü içine alan faaliyetler bütünüdür. Bu tanımdan yola çıkarak tersine lojistik, kullanılan mamulün nihai tüketiciden alınarak üretimin orijin noktasına geri dönüşümünü, taşınmasını sağlamaktadır. Bir sonraki aşama geri dönüşümü sağlanan malın tekrardan üreticiler tarafından kullanılabilecek ürünler haline getirilmesidir (Fleischmann, 1997). Diğer bir tanımdaysa lojistiğin geri dönüşümündeki rolünü ortaya koyan tersine lojistik: kullanılabilirliği sona ermiş 
ürünlerin yeniden kullanılabilir hale getirilip değer kazandırılarak, hammaddelerin kontrollü şekilde kullanılmasıyla atıkların azaltılmasını ilke edinmiş çalışmalar olarak nitelendirilmektedir (Coşkun, 2011).

Tersine lojistikte, üreticiye geri dönmüş ürünlerle ilgili uygulanabilecek yollar ve yöntemler Tablo 1'de belirtilmiştir (Nakiboğlu, 2007).

\section{Tablo 1.Tersine Lojistikte Uygulanan Faaliyetler Tanımlan}

\begin{tabular}{ll}
\hline İşlemler & Uygulamalar \\
\hline Ürünün geliştirilmesi (upgrade) & $\begin{array}{l}\text { Ürünlerin işlevlerini arttırarak çeşitlendiren uygula- } \\
\text { malar }\end{array}$ \\
\hline Yeniden işlenmesi (reprocessing) & $\begin{array}{l}\text { Ürüne değer katma, ürünü geliştirerek ürünün yeni- } \\
\text { den üretilmesi sırasında uygulanan işlemler }\end{array}$ \\
\hline Yeniden üretilmesi (remanufacturing) & $\begin{array}{l}\text { Kullanılan ürünün, yeni üretilmiş bir ürünün özellik- } \\
\text { leri seviyesinde ya da bu seviyeden daha yüksek bir } \\
\text { seviyede değerlere sahip olmasını sağlayan işlemler }\end{array}$ \\
\hline Ürünün yenileştirilmesi (refurbishment) & $\begin{array}{l}\text { Ürünlerin istenen değer düzeyine ulaşmasının mini- } \\
\text { mum maliyetle sağlandığı işlemler süreci }\end{array}$ \\
\hline Yenileme (recondition) & $\begin{array}{l}\text { Kullanılmışürünün en az yenisin seviyesine getiril- } \\
\text { mesine olanak sağlayan faaliyetlerdir. }\end{array}$ \\
\hline Geri dönüşüm (recycle) & $\begin{array}{l}\text { Ürün veya malın çöp olarak nitelendirilmesinden } \\
\text { sonra materyallerinin geri dönüştürülmesini sağla- } \\
\text { yan uygulama }\end{array}$ \\
\hline $\begin{array}{l}\text { Ürünün yeniden değerlendirilmesi } \\
\text { (revalorization) }\end{array}$ & $\begin{array}{l}\text { Kullanılmış olan ürünlerin değerinin yeniden kazanı- } \\
\text { labilmesi için uygulanan süreç }\end{array}$ \\
\hline Ürünün yeniden kullanımı \\
(reuse) & $\begin{array}{l}\text { Tüketicinin kullanmayacağı ürünün yeniden üretil- } \\
\text { mesi ya da kullanılmasının devam edilmesini sağla- } \\
\text { yan faaliyet }\end{array}$ \\
\hline Ürün yamyamlaştırması \\
(cannibalization)
\end{tabular}

Küreselleşme ile birlikte, müşterilerin ürünlere yönelik bilgilerinin artması neticesinde, satınalma tercihleri ve isteklerinde farklılaşma olmaktadır (Tekin ve Sayın, 2017). Bu farklılıklar, ülkelerin dikkatlerini lojistik ve tersine lojistik kavramlarına çevirmektedir. Tersine lojistiğin öneminin anlaşılmasıyla, çevre koruyucu tarafından yasal düzenlemeler oluşturularak bu sayede işletmelerin de tersine lojistik faaliyetlerine daha fazla önem vermeye başlamasına olanak sağlanmaktadır (İrak ve Kurt, 2019).

Tersine lojistiğin faydaları şu şekilde sıralanmaktadır (Nakıboğlu, 2007); 
- Değerin yeniden kazanılması: İlk üretim esnasında katma değer katılmış ürünün malzemelerinde bulunan ve mamulün tekrar geri dönüştürülememesi halinde kaybedilecek değerin yeniden kazanılması,

- Kar maksimizasyonunun sağlanması: Ürünün geri dönüştürülmesi esnasında enerji, işçilik, hammadde ve stokların saklanabilmesi gibi maliyetlerin azaltılarak kar elde edilmesi,

- Çevre sorumluluklarının öneminin kavranması: Atıkların tekrar değerinin kazandırılması için dönüştürülmesi, çevreye zarar verebilecek maddelerin azaltılması, kişilerin ve işletmelerin bilgilendirilmesi,

- Müşteriyle ilişkilerin geliştirilmesi: ürünün satış aşamasından sonra verilebilecek hizmetleri iyileştirme, tüketiciye ürünle alakalı oluşabilecek herhangi bir sorunda, iade kabulü garantisi verebilme gibi müşteriyle olan ilişkilerin geliştirmesi olarak tanımlanmaktadır.

Tersine lojistik faaliyetlerinin uygulanma nedenleri: ekonomik nedenler, kanuni zorunluluklar ve sosyal sorumluluk olarak üç başlıkta incelenmektedir.

Ekonomik Nedenler: Ürünlerin yeniden kullanılacak şekilde dönüştürülmesi yakın zamanda oluşan bir işlem değildir. Plastiklerin, kâğıtların, metallerin geri dönüşümleri uzun yıllar boyunca yapılmaktadır. Bu ürünlerin tamamen yok edilmesi yerine, dönüştürülerek tekrar üretim döngüsüne katılması ekonomik olarak daha faydalı olmaktadır. Bu sebeple son yıllarda geri dönüşüme olan ilgi zamanla artmaktadır (Karaçay, 2005).

Kanuni Zorunluluklar: Herhangi bir ürünü işletme tarafından iade alınmasının, geri kabul edilmesinin yargı tarafından desteklenerek belirli bir kural çerçevesinde oluşturulmasına olanak sağlamaktadır (Şengül, 2011). Üreticiler bir mamulün üretim aşamasından tüketiciye dağıtılarak, tüketici tarafından atık haline gelene kadar geçen tüm aşamalardan sorumludur. Bunun yanı sıra işletmeler, ürünün ambalajlanması ve satış sonrası hizmetlerinden de sorumlu tutulmaktadır (Coşkun, 2011).

Sosyal Sorumluluk: Tüketimin artması ile tüketim alışkanlıklarının değişmesi; hammaddenin azalmasına, atıkların artmasına ve çevrede büyük oranda tahribat oluşmasına neden olmaktadır. Bu konuda ülkeler meydana 
gelen atık üretiminin azaltılması ve hammaddelerin kontrollü tüketilmesi için üreticilere sorumluluklar vermektedir (Demirel ve Gökçen, 2008).

Geçmişten günümüze kadar atıklar çevreye zarar vermekte, bu nedenle atıkların bertaraf edilme ihtiyacı duyulmaktadır (Tenikler, 2007). Bu ihtiyaçlar neticesinde geri dönüşüm kavramı ortaya çıkmaktadır. Geri dönüşüm, ömrü bitmiş çöp olarak nitelendirilen ürünlerin yeniden değerlendirilmesinde, atıkların bir takım yöntem ve işlemlerden geçerek tekrar hammaddeye dönüştürülüp üretim aşamasına dahil edilerek kullanılabilecek hale getirilmesi şeklinde tanımlanabilmektedir. Geri dönüşümün faydaları ise aşağıda yer almaktadır:

- Çevrenin zarar görmesinin önüne geçilerek, kirliliğin azaltılması,

- Doğal kaynakların kontrollü bir şekilde kullanılması sağlanarak korunmasi,

- Enerji tasarrufunun sağlanması,

- Atıkların dönüş̧ürülmesiyle, depolama alanlarının daha tasarruf edilecek şekilde kullanılması şeklinde sıralanmaktadır (Aydın, 2007).

Çevre ve ekolojik dengenin korunması için evsel atıklarda da geri dönüşüm uygulaması yapılmaktadır. Evlerimizde kullanımdan düşmüş çöp olarak nitelendirilen ihtiyaç duymadığımız ürün ve maddelere evsel atık denmektedir. Evlerimizde kullandığımız yiyeceklerden, sebze ve meyvelerden oluşan atıklar, atık su ve yağlar, ürünlerin ambalajları, cam, metal veya plastik kutular, kullanılmayan elbise ve eşyalar, poşetler, piller, kağıt, karton, kitap gibi ürünler, ilaç atıkları evsel atık olarak nitelendirilmektedir. Dünya Bankası tarafından yayınlanan rapora göre 2016 yılında, dünya kentleri günde 2 milyar ton katı atık üretmektedir. Üretilen bu atıkların, kişi başına düşen günlük miktarı 0.74 kilogramdır. Hızlı nüfus artışı ve kentleşmeyle birlikte, 2050'de yıllık atık üretiminin 2016 yılından \% 70 artarak 3.40 milyar tona yükselmesi beklenmektedir (worldbank.org, 2019). Bu oranlar dikkate alındığında, atıkların bertaraf edilmesinin önemi gözle görülür bir şekilde ortaya çıkmaktadır. 


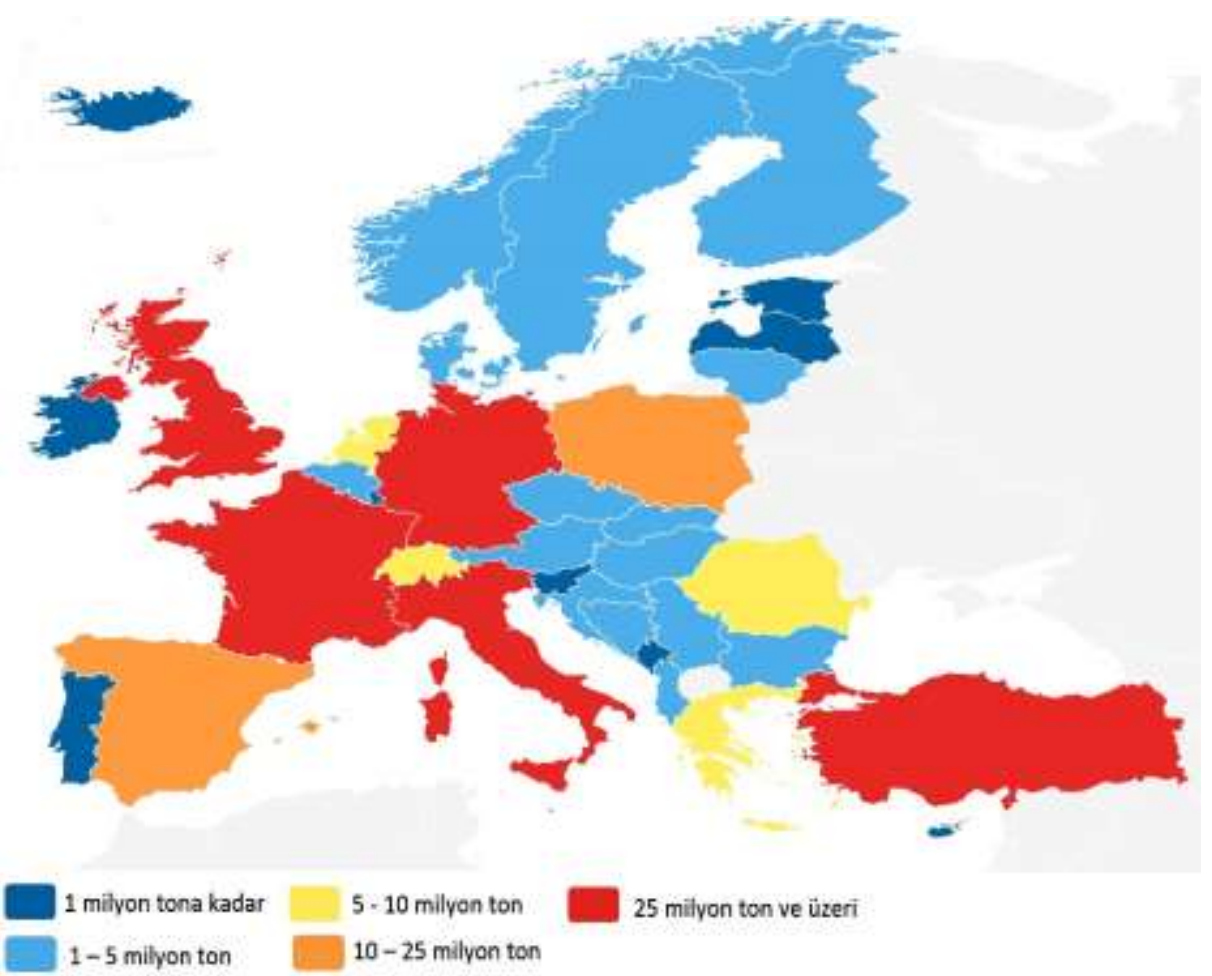

Şekil 1. Avrupa Ülkelerinde Evsel Atık Miktarn (Kaynak:Eurostat, 2018)

2016 yılında, Eurostat'ın yayınladığı verilere göre Avrupa Birliği ülkelerinin toplam evsel atık miktarı 247 milyon tona ulaşmaktadır. 2006 yılına göre evsel atık miktarı \%5'lik bir oranda azalım göstermektedir.

En fazla atık oluşan $A B$ üye ülkeleri:

- Almanya ilk sirada 52 ton,

- Fransa ikinci sirada 34 ton,

- İngiltere üçüncü sırada 32 ton,

- İtalya ise dördüncü sırayla 30 ton olarak karşımıza çıkmaktadır.

2016 yılında, Türkiye'de günlük 34 ton evsel atık oluşmaktadır. 2006 yılına oranla ise Türkiye' de evsel atık \%12 oranında artış göstermiştir. 


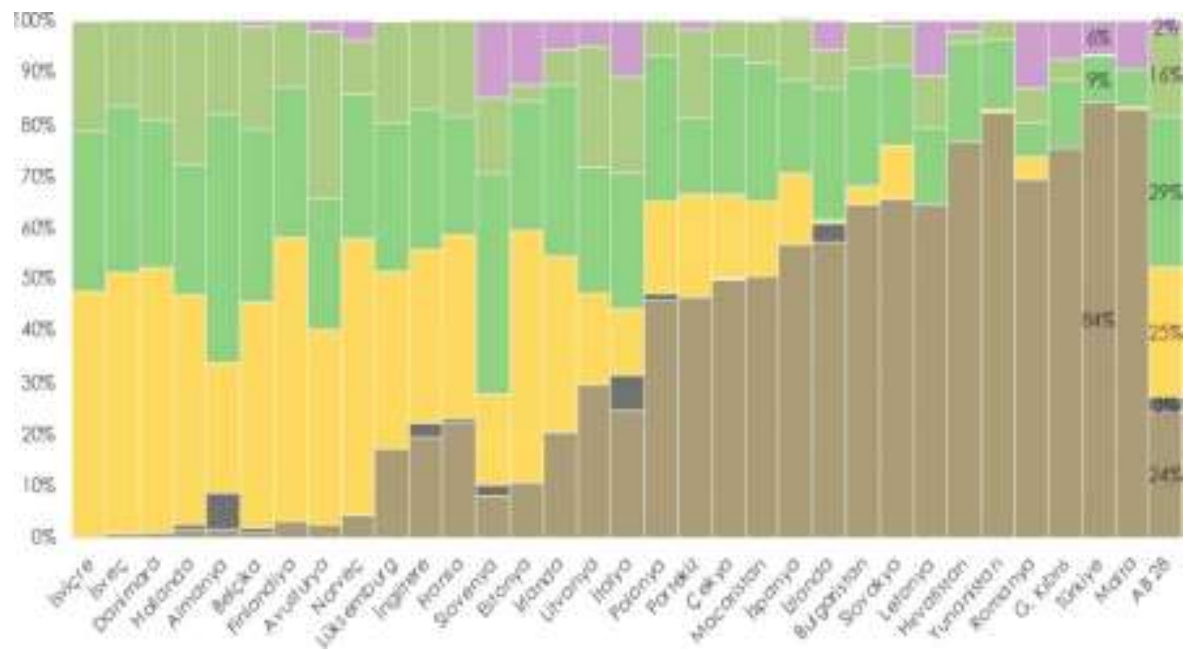

Şekil 2. Avrupa Birliği ülkeleri ve Türkiye'de Evsel Atıklarnn Yönetimi (2016)

(Kaynak: Eurostat, 2018)

Şekil 2'de diğer ülkelere oranla Türkiye'nin:

- \%84 oranında düzenli(+vahşi) depolamaya,

- \%9 oranında geri dönüşüme,

- \%6 oranında da diğer yöntemlere başvurduğu görülmektedir.

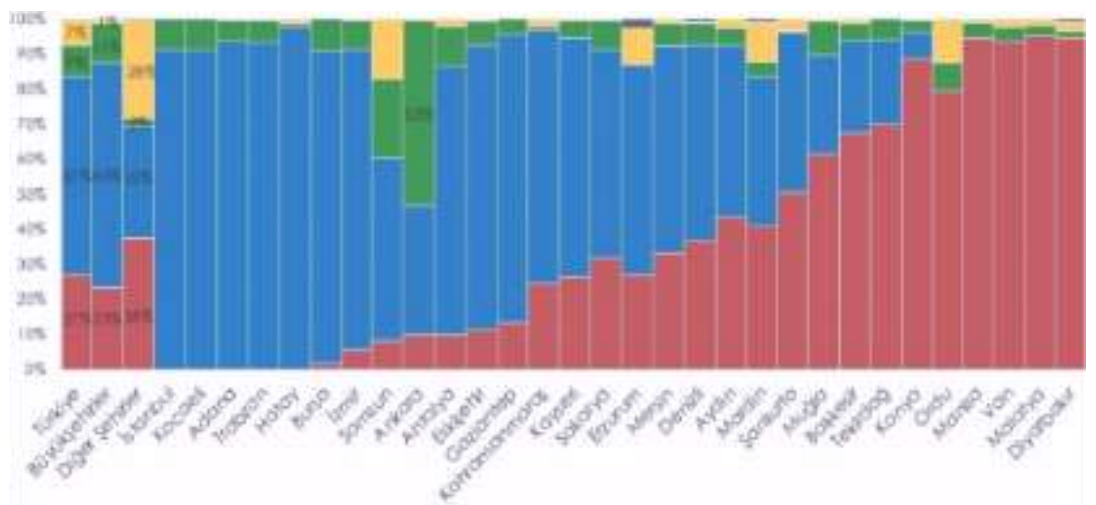

Şekil 3. Büyükşehirlerde Evsel Atıklarn Yönetimi (2016) (Kaynak: TüIK, 2018)

Büyükşehirlerde evsel atıkların yöntemlerine Şekil 3'de yer aldığı üzere, ilk sırayı vahşi depolama yöntemleri almaktadır. Düzenli depolama yöntemi 
ise diğer üç yönteme oranla daha çok tercih edilmektedir. Geri kazanım yapmaya çalışan belediyelerin oranı, diğer oranlar arasında oldukça az olmaktadır (Solak ve Pekküçükşen, 2018: 665). Vahşi depolama yöntemiyle, atıkların zararı olmayacağı düşünülerek, gözlerden uzak boş alanlara dökülmesi ya da gömülerek depolanması insan sağlığını ve çevreyi ciddi anlamda tehdit etmektedir. Bu depolama yöntemi, yer altı ve yer üstü kaynakların kirletmekte, insan sağlığında ciddi problemler oluşturmakta görüntü kirliliğine neden olmaktadır. Evsel atıklarda, vahşi depolamayı en fazla yapan üç ilin oranları şu şekildedir:

- Malatya \%92,

- Manisa \%91,

- Diyarbakır \%90.

$\mathrm{Bu}$ oranlardan görüldüğü üzere, ilgili belediyelerin bir an önce bu çalışmalar yaparak, atıkların insan sağllğına zarar vermeden geri dönüştürülmesi veya depolanmasını sağlanması gerekmektedir.

Çevre ve atık konusunda, Türkiye'de çevre bakanlığı tarafından ulusal atık yönetim planı hazırlanarak, 2023 yılına dair planlamalar yapılmaktadır. Ulusal atık yönetimi 2023 hedefleri arasında yer alan bazı hususlar:

- 2023 yılında oluşan atı̆ğı; \% 35'inin geri kazanım, \% 65 inin düzenli depolama yönetimi ile bertaraf edilmesi,

- Düzensiz döküm sahalarının sslah edilerek vahşi depolama sisteminin azaltılması,

- İnşaatlarda oluşan moloz atıklarının ve hafriyat topraklarının belirlenen yerlerde toplanmasi,

- Özel atıkların (tıbbi, kimyasal vb.) toplamanması ve geri kazanımlarına verimin arttırılmasi,

- Tehlikeli atıkların geri kazanımı, bertarafı ve depolanması için ilave tesis yatırımlarının yapılması hedef 2023 planları arasında yer almaktadir.

Tahmini belediye atığı miktarlarının yer aldığı Şekil 4 incelendiğinde, Türkiye'nin 2014 atık verileri; kişi başı atık miktarı yaklaşık 27,13 milyon ton/yıl olduğu görülmektedir. Yapılan atık tahmini hesaplamalarında; 2023 yılında belediye atıklarının 33 milyon ton olması beklenmektedir. 


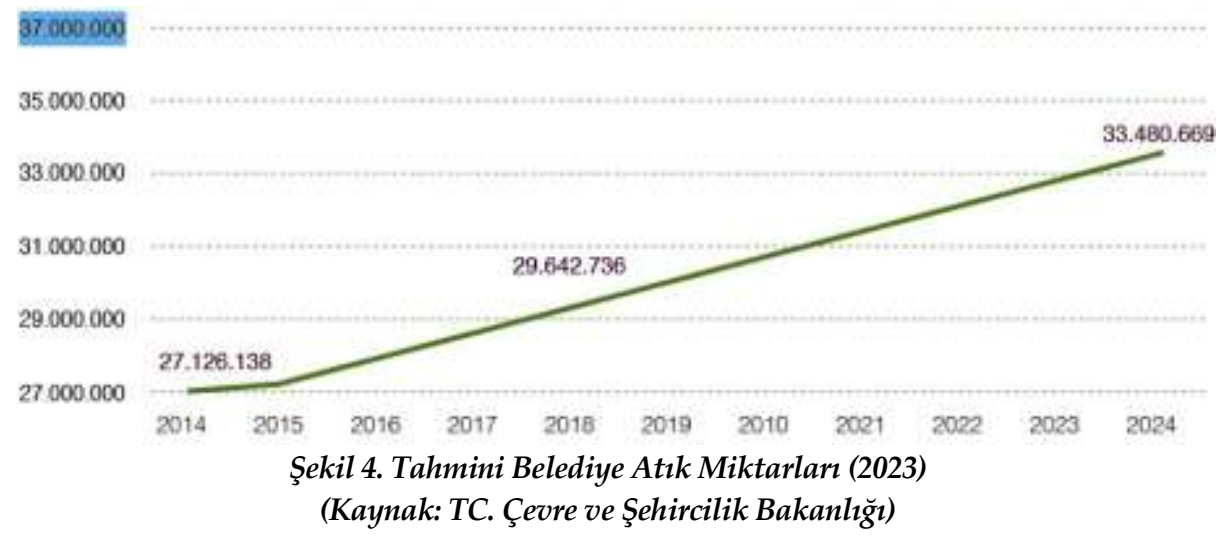

Ulusal atık yöntem planı ile artan atık miktarının, çevreye canlılara etkisinin azaltılarak, ekonomiye katkısının sağlanması için en uygun şekilde geri dönüşüm işlemleri planlanmakta ve önemli adımlar atılmaktadır.

\section{Araştırmanın Yöntemi ve Kapsamı}

Çalışmamızda, bireylerin atık konusunda farkındalıklarının incelenmesi amaçlanmıştır. Hazırlanan soru formu aracilığıyla hane bireylerinin atıklar ve çevreye duyarlılıkları hakkında bilgiler toplanmıştır. Çalışma, birebir görüşme ve telefonda görüşme yapılarak gerçekleştirilmiştir.

Araştırmanın çalışma grubu, Karaman merkezinde 124'ü kadın ve 86'sı erkek toplam 210 hane bireylerinden oluşmaktadır. Bireylerin demografik özellikleri Tablo 2'de yer almaktadır.

Tablo 2' de demografik özelliklere incelendiği takdirde, örneklem grubunun:

- Cinsiyet dağılımı, \%59,1'lik kısmının kadın ve \%40,9'luk kısmının erkek olduğu görülmektedir.

- Yaş aralıklarının ise \%4,8'lik kısmının 17 ve altı yaşlarında, $\% 27,1^{\prime}$ lik kısmının 18-25 yaşlarında, \%36,2'lik kısmının 26-35 yaşlarında, \%12,4 lük kısmının 36-45 yaşlarında, \%11,9'luk kısmının 46-59yaşlarında , $\% 7,6^{\prime}$ lik kısmının ise 60 ve üstü yaşlarında olduğu görülmektedir.

- Kişilerin \%62,9 oranında evli, \%37,1 oranında bekar olduğu anlaşılmaktadir. 
- Grubun \%11,4'ünün ilkokul, \%30,5'inin lise, \%40,9'unun üniversite, $\% 17,2$ 'sinin lisansüstü eğitim aldıkları görülmektedir.

Tablo 2. Çalışma Grubunun Demografik Özellikleri

\begin{tabular}{|c|c|c|c|}
\hline \multicolumn{4}{|c|}{ Çalışma Grubunun } \\
\hline \multicolumn{2}{|c|}{ Demografik Özellikleri } & $\mathbf{N}$ & $\%$ \\
\hline \multirow[t]{2}{*}{ Cinsiyet } & Kadın & 124 & 59,1 \\
\hline & Erkek & 86 & 40,9 \\
\hline \multirow{6}{*}{ Yaş } & 17 ve altı & 10 & 4,8 \\
\hline & $18-25$ & 57 & 27,1 \\
\hline & $26-35$ & 76 & 36,2 \\
\hline & $36-45$ & 26 & 12,4 \\
\hline & $46-59$ & 25 & 11,9 \\
\hline & 60 ve üstü & 16 & 7,6 \\
\hline \multirow[t]{2}{*}{ Medeni Hal } & Evli & 132 & 62,9 \\
\hline & Bekar & 78 & 37,1 \\
\hline \multirow{4}{*}{ Eğitim Düzeyi } & İkokul & 24 & 11,4 \\
\hline & Lise & 64 & 30,5 \\
\hline & Üniversite & 86 & 40,9 \\
\hline & Lisansüstü & 36 & 17,2 \\
\hline \multirow[t]{2}{*}{ Çalışma Durumu } & Evet & 111 & 52,9 \\
\hline & Hayır & 99 & 47,1 \\
\hline \multirow{5}{*}{ Aile Üye Sayısı } & 2 veya daha az & 40 & 19 \\
\hline & $3-4$ & 89 & 42,4 \\
\hline & $5-7$ & 68 & 32,4 \\
\hline & 8 ve daha fazla & 13 & 6,2 \\
\hline & & 210 & 100 \\
\hline
\end{tabular}

- Kişilerin 52,9'unun herhangi bir işgücünde çalıştıkları, \%47,1'inin ise çalışmadığı tespit edilmektedir

- Aile sayılarının \%19'u 2 veya daha az, \%42,4'üu 3-4 kişi, 32,4'ü 5-7 kişi, $\% 6,2$ si ise 8 ve daha fazla kişiden oluştuğu görülmektedir.

\section{Veri Toplama Araçları}

Araştırmada elde edilen verilere, soru formu aracilığı ulaşılmıştır. Soru formu iki bölümden oluşmaktadır.

Kişisel Bilgi Formu: Birinci bölüm, araştırmaya katılan bireylerin demografik özelliklerinin tespit edilmesine yönelik altı adet sorudan oluşmaktadır. Demografik bilgi soruları, araştırmada yer alan örneklem grubun cinsiyet, yaş, medeni hal, eğitim düzeyi gibi özelliklerini belirlemeyi amaçlamaktadır. 
Çevresel Bilincin Ölçülmesine Ait Bilgi Formu: İkinci bölümü ise, bireylerin çevre bilincinin belirlemesi ve çevreye, atıklara karşı davranışlarının incelenebilmesi için 16 adet sorudan oluşmaktadır. Çevre bilinci sorularını içeren kısımda ise hane halkının atıklar karşısında tutumunu, alışkanlıklarını, tespit edebilmek amaçlanmaktadır.

\section{Anket Formunun Uygulanmast}

Soru formu, daha önce yapılmış çalışmalardan esinlenerek, konu ile ilgii çalışma yapan akademisyenlerinde görüşleri alınarak hazırlanmıştır. Araştırmada seçilen bireyler farklı hanelerden rastgele olarak belirlenmiştir. Anketin yapılabilmesi için bireylerden gerekli izinler alınmıştır. Bireylere araştırmanın amacı anlatılmış ve formda anlaşılmayan sorular açıklanarak bilgilendirme yapılmıştır. Anket uygulaması, Eylül ve Aralık 2019 tarihleri arasında Karaman ilinde uygulanmıştır.

\section{Bulgular}

Bireylerin atıklarn ayrıştırılması ve atıklarn geri dönüşümüyle ilgili tutumlarmın bireylerin cinsiyetlerine göre farklılı göstemesine ilişkin bulgular

Tablo 3.Cinsiyet Değişkenine Göre Çevre Bilincinin Değerlendirilmesi

\begin{tabular}{|c|c|c|c|c|c|}
\hline \multirow[t]{2}{*}{ Değiş̧kenler } & & \multicolumn{2}{|c|}{ Kadın } & \multicolumn{2}{|c|}{ Erkek } \\
\hline & & $\mathbf{N}$ & $\%$ & $\mathbf{N}$ & $\%$ \\
\hline \multirow{2}{*}{$\begin{array}{l}\text { Atıkların geri } \\
\text { dönüştürülmesine katkısı }\end{array}$} & Olumlu & 80 & $\% 64.5$ & 50 & $\% 58.1$ \\
\hline & Olumsuz & 44 & $\% 35.5$ & 36 & $\% 41.9$ \\
\hline \multirow{5}{*}{$\begin{array}{l}\text { En çok geri dönüşümü̈ } \\
\text { yapılabilen madde }\end{array}$} & Kağıt & 40 & $\% 32.3$ & 25 & $\% 29.1$ \\
\hline & Cam & 5 & $\% 4$ & 10 & $\% 11.6$ \\
\hline & Plastik & 10 & $\% 8.1$ & 8 & $\% 9.3$ \\
\hline & Pil & 5 & $\% 4$ & 25 & $\% 29.1$ \\
\hline & Yağ & 64 & $\% 51.6$ & 18 & $\% 20.9$ \\
\hline \multirow[t]{2}{*}{ Çevreye karşı duyarlılığı } & Olumlu & 75 & $\% 60.5$ & 45 & $\% 52.3$ \\
\hline & Olumsuz & 49 & $\% 39.5$ & 41 & $\% 47.7$ \\
\hline
\end{tabular}

Tablo 3'te bireylerin atıkların ayrıştırılması ve atıkların geri dönüşümüyle ilgili tutumlarının, bireylerin cinsiyetlerine göre bir farklılık göstermesine ilişkin bulgular belirtilmiştir. Elde edilen verilere göre kadınların oluşturduğu örneklem grubun, erkeklerin oluşturduğu örneklem grubuna göre çevreye 
karşı daha duyarlı olduğu saptanmıştır. Her iki örneklem grubunda, daha çok kağıt atıklarının dönüşümünde dikkat edildiği tespit edilmiştir.

Tablo 4. Cinsiyet Değişkenine Göre Günlük Evlerden Çıkan Atık Miktan

\begin{tabular}{|c|c|c|c|c|c|}
\hline \multirow{2}{*}{\multicolumn{2}{|c|}{$\begin{array}{l}\text { Günlük Evlerden } \\
\text { Çıkan Atık Miktarı }\end{array}$}} & \multicolumn{2}{|c|}{ Kadın } & \multicolumn{2}{|c|}{ Erkek } \\
\hline & & \multirow{2}{*}{$\begin{array}{l}\mathbf{N} \\
57\end{array}$} & \multirow{2}{*}{$\begin{array}{l}\% \\
\% 45.9 \\
\end{array}$} & \multirow{2}{*}{$\begin{array}{l}\mathbf{N} \\
32\end{array}$} & \multirow{2}{*}{$\begin{array}{l}\% \\
\% 37,2\end{array}$} \\
\hline Kağıt & $500 \mathrm{gr}$ ve daha az & & & & \\
\hline & $500 \mathrm{gr}-1 \mathrm{~kg}$ & 35 & $\% 28.2$ & 23 & $\% 26,7$ \\
\hline & $1 \mathrm{~kg}-2 \mathrm{~kg}$ & 23 & $\% 18.6$ & 11 & $\% 12.8$ \\
\hline & $2 \mathrm{~kg}$ ve üstü & 9 & $\% 7.3$ & 20 & $\% 23,3$ \\
\hline \multirow[t]{4}{*}{ Cam } & 500 gr ve daha az & 32 & $\% 25,8$ & 37 & $\% 43.1$ \\
\hline & $500 \mathrm{gr}-1 \mathrm{~kg}$ & 45 & $\% 36,3$ & 18 & $\% 20,9$ \\
\hline & $1 \mathrm{~kg}-2 \mathrm{~kg}$ & 20 & $\% 16,1$ & 15 & $\% 17,4$ \\
\hline & $2 \mathrm{~kg}$ ve üstü & 27 & $\% 21,8$ & 16 & $\% 18,6$ \\
\hline \multirow[t]{4}{*}{ Plastik } & 500 gr ve daha az & 40 & $\% 32,2$ & 22 & $\% 25,6$ \\
\hline & 500 gr- $1 \mathrm{~kg}$ & 25 & $\% 20,2$ & 34 & $\% 39,5$ \\
\hline & $1 \mathrm{~kg}-2 \mathrm{~kg}$ & 32 & $\% 25,8$ & 25 & $\% 29,1$ \\
\hline & $2 \mathrm{~kg}$ ve üstü & 27 & $\% 21,8$ & 5 & $\% 5,8$ \\
\hline \multirow[t]{4}{*}{ Pil } & 500 gr ve daha az & 47 & $\% 37,9$ & 17 & \%19.8 \\
\hline & 500 gr- $1 \mathrm{~kg}$ & 32 & $\% 25,8$ & 35 & $\% 40,6$ \\
\hline & $1 \mathrm{~kg}-2 \mathrm{~kg}$ & 27 & $\% 21,8$ & 25 & $\% 29.1$ \\
\hline & $2 \mathrm{~kg}$ ve üstü & 18 & $\% 14,5$ & 9 & $\% 10.5$ \\
\hline \multirow[t]{4}{*}{ Yağ } & 500 gr ve daha az & 37 & $\% 29,8$ & 23 & $\% 26,7$ \\
\hline & 500 gr- 1 kg & 50 & $\% 40,3$ & 19 & $\% 22,1$ \\
\hline & $1 \mathrm{~kg}-2 \mathrm{~kg}$ & 25 & $\% 20,2$ & 27 & $\% 31,4$ \\
\hline & $2 \mathrm{~kg}$ ve üstü & 12 & $\% 9.7$ & 17 & \%19,8 \\
\hline
\end{tabular}

Tablo 4'de yer aldığı üzere, günlük evden çıkan atık miktarının bireylerin cinsiyetine göre değişmesine ilişkin sonuçlara yer verilmiştir. Ulaşılan verilere göre günlük evden çıkan atık miktarı, cinsiyet faktörüne göre değişiklik göstermektedir.

Bireylerin atıkların ayrıştırlması ve atıkların geri dönüşümüyle ilgili tutumlarının bireylerin yaş bilgilerine göre farklllık göstermesine ilişkin bulgular

Tablo 5'te örneklem grubunun atıkların ayrıştırılması ve atıkların geri dönüşümüyle ilgili tutumlarının, yaş kriterine göre bir farklılık gösermesine ilişkin bulgulara yer verilmiştir. Ulaşılan verilere göre çevre bilincinin, yaş faktörüne göre değişiklik gösterdiği sonucuna ulaşılmaktadır. 17 ve altında bulunan örneklem grubun diğer gruplara göre atıkların dönüştürülmesinde katkısının en az, 36-45 yaş grubunun ise katkısının en fazla olduğu görülmektedir. 
Tablo 5. Yaş Değgişkenine Göre Çevre Bilincinin Değerlendirilmesi

\begin{tabular}{|c|c|c|c|c|c|c|c|c|c|c|c|c|c|}
\hline \multirow{2}{*}{ Değişkenler } & & \multicolumn{2}{|c|}{17 ve Altı } & \multicolumn{2}{|c|}{ 18-25 } & \multicolumn{2}{|c|}{$26-35$} & \multicolumn{2}{|c|}{$36-45$} & \multicolumn{2}{|c|}{$46-59$} & \multicolumn{2}{|c|}{60 ve üstü } \\
\hline & & $\mathbf{N}$ & $\%$ & $\mathbf{N}$ & $\%$ & $\mathbf{N}$ & $\%$ & $\mathbf{N}$ & $\%$ & $\mathbf{N}$ & $\%$ & $\mathbf{N}$ & $\%$ \\
\hline \multirow{2}{*}{$\begin{array}{l}\text { Atıkların } \\
\text { geri dönüştü- } \\
\text { rülmesine } \\
\text { katkısı }\end{array}$} & Olumlu & 2 & $\% 20$ & 15 & $\% 26.3$ & 25 & $\% 32.9$ & 15 & $\% 57.7$ & 10 & $\% 40$ & 4 & $\% 25$ \\
\hline & $\begin{array}{l}\text { Olum- } \\
\text { suz }\end{array}$ & 8 & $\% 80$ & 42 & $\% 73.7$ & 51 & $\% 67.1$ & 11 & $\% 42.3$ & 15 & $\% 60$ & 12 & $\% 75$ \\
\hline \multirow{5}{*}{$\begin{array}{l}\text { En çok } \\
\text { geri } \\
\text { dönüşüumü } \\
\text { yapılabilen } \\
\text { madde }\end{array}$} & Kağıt & 4 & $\% 40$ & 17 & $\% 29.8$ & 30 & $\% 39.5$ & 10 & $\% 38.5$ & 7 & $\% 28$ & 5 & $\% 31.2$ \\
\hline & Cam & 1 & $\% 10$ & 8 & $\% 14.1$ & 20 & $\% 26.3$ & 2 & $\% 7.7$ & 4 & $\% 16$ & 1 & $\% 6.3$ \\
\hline & Plastik & 2 & $\% 20$ & 7 & $\% 12.3$ & 5 & $\% 6.6$ & 5 & $\% 19.2$ & 5 & $\% 20$ & 2 & $\% 12.5$ \\
\hline & Pil & 2 & $\% 20$ & 20 & $\% 35.1$ & 10 & $\% 13.1$ & 6 & $\% 23.1$ & 6 & $\% 24$ & 6 & $\% 37.5$ \\
\hline & Yăg & 1 & $\% 10$ & 5 & $\% 8.7$ & 11 & $\% 14.5$ & 3 & \%11.5 & 3 & $\% 12$ & 2 & $\% 12.5$ \\
\hline \multirow{2}{*}{$\begin{array}{l}\text { Çevreye } \\
\text { karşı duyarl- } \\
\text { lığı }\end{array}$} & Olumlu & 3 & $\% 30$ & 14 & $\% 24.6$ & 24 & $\% 31.6$ & 14 & $\% 53.8$ & 9 & $\% 36$ & 3 & \%18.7 \\
\hline & $\begin{array}{l}\text { Olum- } \\
\text { suz }\end{array}$ & 7 & $\% 70$ & 43 & $\% 75.4$ & 52 & $\% 68.4$ & 12 & $\% 46.2$ & 16 & $\% 64$ & 13 & $\% 81.3$ \\
\hline
\end{tabular}

Tablo 6.Yaş Değişkenine Göre Günlük Evlerden Çıkan Atık Miktarı

\begin{tabular}{|c|c|c|c|c|c|c|c|c|c|c|c|c|c|}
\hline \multirow{2}{*}{$\begin{array}{l}\text { Günlük } \\
\text { Miktarı }\end{array}$} & \multirow{2}{*}{ Evlerden Çıkan Atık } & \multicolumn{2}{|c|}{17 ve Altı } & \multicolumn{2}{|c|}{$18-25$} & \multicolumn{2}{|c|}{ 26-35 } & \multicolumn{2}{|c|}{$36-45$} & \multicolumn{2}{|c|}{ 46-59 } & \multicolumn{2}{|c|}{60 ve üstü } \\
\hline & & $\mathbf{N}$ & $\%$ & $\mathbf{N}$ & $\%$ & $\mathbf{N}$ & $\%$ & $\mathbf{N}$ & $\%$ & $\mathbf{N}$ & $\%$ & $\mathbf{N}$ & $\%$ \\
\hline \multirow[t]{4}{*}{ Kağıt } & 500 gr ve daha az & 2 & 20 & 17 & 29,8 & 32 & 42,1 & 12 & 46,1 & 5 & 20 & 6 & 37,4 \\
\hline & 500 gr- $1 \mathrm{~kg}$ & 4 & 40 & 21 & 36,8 & 25 & 32,9 & 9 & 34,7 & 17 & 68 & 8 & 50 \\
\hline & $1 \mathrm{~kg}-2 \mathrm{~kg}$ & 3 & 30 & 12 & 21,1 & 13 & 17,1 & 2 & 7,7 & 1 & 4 & 1 & 6.3 \\
\hline & $2 \mathrm{~kg}$ ve üstü & 1 & 10 & 7 & 12,3 & 6 & 7,9 & 3 & 11,5 & 2 & 8 & 1 & 6.3 \\
\hline \multirow[t]{4}{*}{ Cam } & 500 gr ve daha az & 4 & 40 & 23 & 40,2 & 24 & 31,6 & 17 & 65,5 & 16 & 64 & 6 & 37.6 \\
\hline & 500 gr- $1 \mathrm{~kg}$ & 2 & 20 & 12 & 21,1 & 29 & 38,1 & 7 & 26,9 & 4 & 16 & 4 & 25 \\
\hline & $1 \mathrm{~kg}-2 \mathrm{~kg}$ & 1 & 10 & 14 & 24,6 & 12 & 15.8 & 1 & 3,8 & 4 & 16 & 3 & 18,7 \\
\hline & $2 \mathrm{~kg}$ ve üstü & 3 & 30 & 8 & 14.1 & 11 & 14,5 & 1 & 3,8 & 1 & 4 & 3 & 18,7 \\
\hline \multirow[t]{4}{*}{ Plastik } & 500 gr ve daha az & 5 & 50 & 25 & 43,7 & 18 & 23,7 & 9 & 34,6 & 11 & 44 & 5 & 31,3 \\
\hline & 500 gr- $1 \mathrm{~kg}$ & 1 & 10 & 12 & 21,1 & 37 & 48,7 & 11 & 42,3 & 10 & 40 & 5 & 31,3 \\
\hline & $1 \mathrm{~kg}-2 \mathrm{~kg}$ & 2 & 20 & 16 & 28,1 & 14 & 18,4 & 4 & 15,4 & 3 & 12 & 4 & 25 \\
\hline & 2kg ve üstü & 2 & 20 & 4 & 7,1 & 7 & 9,2 & 2 & 7,7 & 1 & 4 & 2 & 12,4 \\
\hline \multirow[t]{4}{*}{ Pil } & 500 gr ve daha az & 1 & 10 & 7 & 12,3 & 26 & 34,2 & 5 & 19,2 & 8 & 32 & 9 & 56,3 \\
\hline & 500 gr- $1 \mathrm{~kg}$ & 5 & 50 & 17 & 29,8 & 30 & 39,5 & 17 & 65,4 & 11 & 44 & 5 & 31,3 \\
\hline & $1 \mathrm{~kg}-2 \mathrm{~kg}$ & 3 & 30 & 20 & 35,1 & 10 & 13,1 & 3 & 11,6 & 4 & 16 & 2 & 12,4 \\
\hline & 2kg ve üstü & 1 & 10 & 13 & 22,8 & 10 & 13,2 & 1 & 3,8 & 2 & 8 & - & - \\
\hline \multirow[t]{4}{*}{ Yağ } & 500 gr ve daha az & 5 & 50 & 33 & 57,8 & 42 & 55,3 & 10 & 38,5 & 20 & 80 & 10 & 62,5 \\
\hline & 500 gr- $1 \mathrm{~kg}$ & 2 & 20 & 12 & 21,1 & 20 & 26,3 & 9 & 34,6 & 3 & 12 & 2 & 12,4 \\
\hline & $1 \mathrm{~kg}-2 \mathrm{~kg}$ & 1 & 10 & 7 & 12,3 & 9 & 11,9 & 5 & 19,2 & 1 & 4 & 3 & 18,8 \\
\hline & 2kg ve üstü & 2 & 20 & 5 & 8,8 & 5 & 6,5 & 2 & 7,7 & 1 & 4 & 1 & 6,3 \\
\hline
\end{tabular}

Tablo-6'da günlük evden çıkan atık miktarının bireylerin yaşlarına göre farklılık gösterip göstermediğine ait verilere ulaşılmaktadır. Ulaşılan verilere göre günlük evden çıan atık miktarının, yaş faktöründen etkilendiği sonucuna ulaşılmaktadır.

Bireylerin atıklarn ayrıştırılması ve atıklarm geri dönüşümüyle ilgili tutumlarnn bireylerin medeni hal durumlarna göre farklilk göstermesine ilişkin bulgular 
Tablo 7. Bireylerin Medeni Hal Durumlarna Göre Çevre Bilincinin Değerlendirilmesi

\begin{tabular}{llllll}
\hline Değişkenler & & \multicolumn{2}{c}{ Evli } & \multicolumn{2}{c}{ Bekar } \\
\cline { 2 - 6 } & & $\mathbf{N}$ & $\mathbf{\%}$ & $\mathbf{N}$ & $\mathbf{\%}$ \\
\hline Atıkların geri dönüştürülmesine katkısı & Olumlu & 72 & $\% 54.5$ & 40 & $\% 51.3$ \\
\cline { 2 - 6 } & Olumsuz & 60 & $\% 45.5$ & 38 & $\% 48.7$ \\
\hline En çok geri dönüşümü yapılabilen madde & Kağıt & 55 & $\% 41.7$ & 35 & $\% 44.9$ \\
\cline { 2 - 6 } & Cam & 15 & $\% 11.4$ & 10 & $\% 12.8$ \\
\cline { 2 - 6 } & Plastik & 12 & $\% 9.1$ & 15 & $\% 19.2$ \\
\cline { 2 - 6 } & Pil & 23 & $\% 17.4$ & 10 & $\% 12.8$ \\
\cline { 2 - 6 } & Yăg & 27 & $\% 20.4$ & 8 & $\% 10.3$ \\
\hline Çevreye karşı duyarlılı̆̆ı & Olumlu & 70 & $\% 53.1$ & 36 & $\% 46.2$ \\
\cline { 2 - 6 } & Olumsuz & 62 & $\% 46.9$ & 42 & $\% 53.8$ \\
\hline
\end{tabular}

Tablo 7'de örneklem grubunun atıkların ayrıştırılarak geri dönüşümüyle ilgili tutumlarının medeni hal durumlarına göre bir çeşitlilik gösterip göstermediğine ilişkin bulgulara yer verilmiştir. Bu bulgulara göre çevre bilinci ve bireylerin atıklar karşısındaki tutumları, medeni hal değişkenine göre farkl1lık göstermektedir. Evli bireylerin bekar bireylere oranla atıkların dönüştürülmesinde daha etkin rol oynadıkları ve buna paralel olarak da çevre bilincinin daha yüksek olduğu tespit edilmiştir.

Tablo 8. Medeni hal durumuna Göre Günlük Evlerden Çıkan Atık Miktarı

\begin{tabular}{|c|c|c|c|c|c|}
\hline \multicolumn{2}{|c|}{ Günlük Evlerden Çıkan Atık Miktarı } & \multicolumn{2}{|c|}{ Evli } & \multicolumn{2}{|c|}{ Bekar } \\
\hline & & $\mathbf{N}$ & $\%$ & $\mathbf{N}$ & $\%$ \\
\hline \multirow[t]{4}{*}{ Kağıt } & 500 gr ve daha az & 33 & 25 & 38 & 48,7 \\
\hline & 500 gr- $1 \mathrm{~kg}$ & 57 & 43,2 & 20 & 25,6 \\
\hline & $1 \mathrm{~kg}-2 \mathrm{~kg}$ & 25 & 18,9 & 14 & 17,9 \\
\hline & $2 \mathrm{~kg}$ ve üstü & 17 & 12,9 & 6 & 7,8 \\
\hline \multirow[t]{4}{*}{ Cam } & 500 gr ve daha az & 59 & 44,7 & 25 & 32,1 \\
\hline & 500 gr- $1 \mathrm{~kg}$ & 24 & 18,2 & 15 & 19,2 \\
\hline & $1 \mathrm{~kg}-2 \mathrm{~kg}$ & 34 & 25,8 & 20 & 25,6 \\
\hline & $2 \mathrm{~kg}$ ve üstü & 15 & 11,3 & 18 & 23,1 \\
\hline \multirow[t]{4}{*}{ Plastik } & 500 gr ve daha az & 54 & 40,9 & 35 & 44,9 \\
\hline & 500 gr- $1 \mathrm{~kg}$ & 28 & 21.2 & 24 & 30.8 \\
\hline & $1 \mathrm{~kg}-2 \mathrm{~kg}$ & 33 & 25 & 16 & 20,5 \\
\hline & $2 \mathrm{~kg}$ ve üstü & 17 & 12.9 & 3 & 3,8 \\
\hline \multirow[t]{4}{*}{ Pil } & 500 gr ve daha az & 68 & 51,5 & 27 & 34,6 \\
\hline & 500 gr- $1 \mathrm{~kg}$ & 28 & 21,2 & 32 & 41,1 \\
\hline & $1 \mathrm{~kg}-2 \mathrm{~kg}$ & 24 & 18,2 & 13 & 16,7 \\
\hline & 2kg ve üstü & 12 & 9,1 & 6 & 7,6 \\
\hline \multirow[t]{4}{*}{ Yağ } & 500 gr ve daha az & 76 & 57,6 & 52 & 66,7 \\
\hline & 500 gr- $1 \mathrm{~kg}$ & 34 & 25,8 & 14 & 17.9 \\
\hline & $1 \mathrm{~kg}-2 \mathrm{~kg}$ & 17 & 12,9 & 7 & 8,9 \\
\hline & $2 \mathrm{~kg}$ ve üstü & 5 & 3,7 & 5 & 6,5 \\
\hline
\end{tabular}


Tablo 8'de günlük evden çıan atık miktarının bireylerin medeni durumlarından etkilenip etkilenmediğini gösteren verilere yer verilmiştir. Bu verilere göre bireylerin medeni durumları evlerden çıkan günlük atık miktarını etkilemektedir.

Bireylerin atıklarn ayrıştırnlması ve atıklarn geri dönüşümüyle ilgili tutumlarnnn bireylerin eğitim düzeylerine göre farklılk göstermesine ilişkin bulgular

Tablo 9'da bireylerin eğitim düzeylerinin atıkların ayrıştııılarak toplanılması ve yeniden kazanılmasına ilişkin sonuçlarda bir etkisinin olup olmadığına dair yapılan araştırmanın bulguları gösterilmektedir. Bu araştırmaya göre bireylerin eğitim düzeyleri, çevre bilincini ve atıklar karşısındaki tutumlarını etkilemektedir. Lisansütü eğitim düzeyinde olan bireylerin diğer bireylere oranla, atıkların geri dönüşümüne katkısı ve çevreye karşı duyarlılı̆̆ının daha fazla olduğu görülmektedir.

Tablo 9. Bireylerin Ĕ̆itim Düzeylerine Göre Çevre Bilincinin Değerlendirilmesi

\begin{tabular}{|c|c|c|c|c|c|c|c|c|c|}
\hline \multirow{2}{*}{ Değişkenler } & & \multicolumn{2}{|c|}{ İlkokul } & \multicolumn{2}{|c|}{ Lise } & \multicolumn{2}{|c|}{ Üniversite } & \multicolumn{2}{|c|}{ Lisansüstü } \\
\hline & & $\mathbf{N}$ & $\%$ & $\mathbf{N}$ & $\%$ & $\mathbf{N}$ & $\%$ & $\mathbf{N}$ & $\%$ \\
\hline \multirow{2}{*}{$\begin{array}{l}\text { Atıkların geri } \\
\text { dönüşstürülmesine } \\
\text { katkısı }\end{array}$} & Olumlu & 10 & $\% 41.7$ & 31 & $\% 48.4$ & 45 & $\% 52.3$ & 20 & $\% 55.6$ \\
\hline & Olumsuz & 14 & $\% 58.3$ & 33 & $\% 51.6$ & 41 & $\% 47.7$ & 16 & $\% 44.4$ \\
\hline \multirow{5}{*}{$\begin{array}{l}\text { En çok geri } \\
\text { dönüşüumü } \\
\text { yapılabilen } \\
\text { madde }\end{array}$} & Kağıtt & 8 & $\% 33.3$ & 25 & $\% 39.1$ & 35 & $\% 40.7$ & 25 & $\% 69.4$ \\
\hline & Cam & 4 & $\% 16.7$ & 20 & $\% 31.3$ & 15 & \%17.4 & 3 & $\% 8.3$ \\
\hline & Plastik & 3 & \%12.5 & 5 & $\% 7.8$ & 10 & \%11.7 & 5 & $\% 13.9$ \\
\hline & Pil & 8 & $\% 33.3$ & 10 & $\% 15.6$ & 15 & \%17.4 & 2 & $\% 5.6$ \\
\hline & Yağ & 1 & $\% 4.2$ & 4 & $\% 6.2$ & 11 & $\% 12.8$ & 1 & $\% 2.8$ \\
\hline \multirow{2}{*}{$\begin{array}{l}\text { Çevreye karşı } \\
\text { duyarlılığı }\end{array}$} & Olumlu & 9 & $\% 37.5$ & 33 & $\% 51.6$ & 50 & $\% 58.1$ & 22 & $\% 61.1$ \\
\hline & Olumsuz & 15 & $\% 62.5$ & 31 & $\% 48.4$ & 36 & $\% 41.9$ & 14 & $\% 38.9$ \\
\hline
\end{tabular}

Tablo 10'da günlük evden çıan atık miktarının, bireylerin eğitim düzeylerinde etkilenip etkilenmediğini gösteren verilere yer verilmiştir. Bu verilere göre bireylerin eğitim düzeyleri evlerden çıkan günlük atık miktarını etkilemektedir. 
Tablo 10. Eğitim düzeyi Değişkenine Göre Günlük Evlerden Çıkan Atık Miktarı

\begin{tabular}{|c|c|c|c|c|c|c|c|c|c|}
\hline \multirow{2}{*}{\multicolumn{2}{|c|}{$\begin{array}{l}\text { Günlük Evlerden Çıkan Atık Mik- } \\
\text { tarı }\end{array}$}} & \multicolumn{2}{|c|}{ İlkokul } & \multicolumn{2}{|c|}{ Lise } & \multicolumn{2}{|c|}{ Üniversite } & \multicolumn{2}{|c|}{ Lisansüstü } \\
\hline & & $\mathbf{N}$ & $\%$ & $\mathbf{N}$ & $\%$ & $\mathbf{N}$ & $\%$ & $\mathbf{N}$ & $\%$ \\
\hline \multirow[t]{4}{*}{ Kağıt } & 500 gr ve daha az & 14 & 58,3 & 37 & 57,8 & 52 & $\% 60,5$ & 21 & $\% 58,4$ \\
\hline & 500 gr- $1 \mathrm{~kg}$ & 8 & 33,3 & 13 & 20,3 & 12 & $\% 13,9$ & 9 & $\% 25$ \\
\hline & $1 \mathrm{~kg}-2 \mathrm{~kg}$ & 1 & 4,2 & 8 & 12,5 & 10 & $\% 11,7$ & 3 & $\% 8,3$ \\
\hline & $2 \mathrm{~kg}$ ve üstü & 1 & 4,2 & 6 & 9,4 & 12 & $\% 13,9$ & 3 & $\% 8,3$ \\
\hline \multirow[t]{4}{*}{ Cam } & 500 gr ve daha az & 8 & 33,3 & 42 & 65,6 & 45 & $\% 52,3$ & 24 & $\% 66,7$ \\
\hline & 500 gr- $1 \mathrm{~kg}$ & 10 & 41,7 & 10 & 15,6 & 29 & $\% 33,8$ & 5 & $\% 13,9$ \\
\hline & $1 \mathrm{~kg}-2 \mathrm{~kg}$ & 4 & 16,7 & 8 & 12,5 & 10 & $\% 11,7$ & 3 & $\% 8,3$ \\
\hline & 2kg ve üstü & 2 & 8,3 & 4 & 6,3 & 2 & $\% 2,2$ & 4 & $\% 11,1$ \\
\hline \multirow[t]{4}{*}{ Plastik } & 500 gr ve daha az & 7 & 29,2 & 39 & 60,9 & 32 & $\% 37,2$ & 19 & $\% 52.8$ \\
\hline & 500 gr- $1 \mathrm{~kg}$ & 12 & 50 & 20 & 31,2 & 20 & $\% 23,3$ & 15 & $\% 41,6$ \\
\hline & $1 \mathrm{~kg}-2 \mathrm{~kg}$ & 4 & 16,6 & 4 & 6,3 & 18 & $\% 20,9$ & 1 & $\% 2,8$ \\
\hline & $2 \mathrm{~kg}$ ve üstü & 1 & 4,2 & 1 & 1,6 & 16 & $\% 18,6$ & 1 & $\% 2,8$ \\
\hline \multirow[t]{4}{*}{ Pil } & 500 gr ve daha az & 9 & 37,5 & 29 & 45,3 & 35 & $\% 40,7$ & 12 & $\% 33,3$ \\
\hline & 500 gr- $1 \mathrm{~kg}$ & 11 & 45,8 & 25 & 39,1 & 25 & $\% 29,1$ & 15 & $\% 41,6$ \\
\hline & $1 \mathrm{~kg}-2 \mathrm{~kg}$ & 3 & 12,5 & 7 & 10,9 & 18 & $\% 20,9$ & 5 & $\% 13,9$ \\
\hline & 2kg ve üstü & 1 & 4,2 & 3 & 4.7 & 8 & $\% 9.3$ & 4 & $\% 11,2$ \\
\hline \multirow[t]{4}{*}{ Yağ } & 500 gr ve daha az & 12 & & 27 & 42,2 & 39 & $\% 45,3$ & 14 & $\% 38.9$ \\
\hline & 500 gr- $1 \mathrm{~kg}$ & 7 & & 10 & 15,6 & 25 & $\% 29,1$ & 10 & $\% 27,8$ \\
\hline & $1 \mathrm{~kg}-2 \mathrm{~kg}$ & 2 & & 18 & 28,1 & 20 & $\% 23,4$ & 9 & $\% 25$ \\
\hline & 2kg ve üstü & 3 & & 9 & 14,1 & 2 & $\% 2,2$ & 3 & $\% 8,3$ \\
\hline
\end{tabular}

Bireylerin atıklarn ayrıştınlması ve atıklarn geri dönüş̧ümüyle ilgili tutumlarını bireylerin çalışıp çalışmadıklarnna göre farklılık göstermesine ilişkin bulgular

Atıkların ayrıştırılması ve yeniden kazanılabilir hale getirilmesinde ve bireylerin çevreye karşı olan tutumlarında, bireylerin çalışma durumuna göre yapılan araştırmaya ait bulgular Tablo 11'de gösterilmektedir. Bu bulgulara göre çalışan bireyler, çalışmayan bireylere göre atıkların dönüştürülmesinde daha etkin rol oynamaktadır. Yine bu sonuç paralelinde çalışan bireylerin çevreye karşı daha duyarlı olduğu görülmektedir.

Tablo 11. Bireylerin Çalışma Durumuna Göre Çevre Bilincinin Değerlendirilmesi

\begin{tabular}{|c|c|c|c|c|c|}
\hline \multirow[t]{2}{*}{ Değişkenler } & & \multicolumn{2}{|c|}{ Çalışan } & \multicolumn{2}{|c|}{ Çalışmayan } \\
\hline & & $\mathbf{N}$ & $\%$ & $\mathbf{N}$ & $\%$ \\
\hline \multirow[t]{2}{*}{ Atıkların geri dönüş̧türülmesine katkısı } & Olumlu & 60 & $\% 54.1$ & 54 & $\% 54.5$ \\
\hline & Olumsuz & 51 & $\% 45.9$ & 45 & $\% 45.5$ \\
\hline \multirow[t]{5}{*}{ En çok geri dönüşümü yapılabilen madde } & Kağıt & 19 & $\% 17.1$ & 35 & $\% 35.3$ \\
\hline & Cam & 23 & $\% 20.7$ & 19 & $\% 19.2$ \\
\hline & Plastik & 18 & $\% 16.2$ & 18 & $\% 18.2$ \\
\hline & Pil & 30 & $\% 27.1$ & 17 & $\% 17.2$ \\
\hline & Yă̆ & 21 & $\% 18.9$ & 10 & $\%$ \%10.1 \\
\hline \multirow[t]{2}{*}{ Çevreye karşı duyarlılığı } & Olumlu & 56 & $\% 50.5$ & 52 & $\% 52.5$ \\
\hline & Olumsuz & 55 & $\% 49.5$ & 47 & $\% 47.5$ \\
\hline
\end{tabular}


Tablo 12. Bireylerin Çalışma Durumuna Göre Günlük Evlerden Çıkan Atık Miktarı

\begin{tabular}{|c|c|c|c|c|c|}
\hline \multicolumn{2}{|c|}{ Günlük Evlerden Çıkan Atık Miktarı } & \multicolumn{2}{|c|}{ Çalışan } & \multicolumn{2}{|c|}{ Çalışmayan } \\
\hline & & $\mathbf{N}$ & $\%$ & $\mathbf{N}$ & $\%$ \\
\hline \multirow[t]{4}{*}{ Kağıt } & 500 gr ve daha az & 38 & $\% 34,2$ & 37 & $\% 37,4$ \\
\hline & 500 gr- $1 \mathrm{~kg}$ & 25 & $\% 22,5$ & 19 & $\% 19,1$ \\
\hline & $1 \mathrm{~kg}-2 \mathrm{~kg}$ & 17 & $\% 15,4$ & 8 & $\% 8,1$ \\
\hline & 2kg ve üstü & 31 & $\% 27,9$ & 35 & $\% 35,4$ \\
\hline \multirow[t]{4}{*}{ Cam } & 500 gr ve daha az & 48 & $\% 43,2$ & 18 & $\% 18,2$ \\
\hline & 500 gr- $1 \mathrm{~kg}$ & 32 & $\% 28,9$ & 42 & $\% 42,4$ \\
\hline & $1 \mathrm{~kg}-2 \mathrm{~kg}$ & 15 & $\% 13,5$ & 20 & $\% 20,2$ \\
\hline & $2 \mathrm{~kg}$ ve üstü & 16 & $\% 14,4$ & 19 & $\% 19,2$ \\
\hline \multirow[t]{4}{*}{ Plastik } & 500 gr ve daha az & 67 & $\% 60.4$ & 39 & $\% 39,4$ \\
\hline & 500 gr- $1 \mathrm{~kg}$ & 21 & $\% 18,9$ & 32 & $\% 32,3$ \\
\hline & $1 \mathrm{~kg}-2 \mathrm{~kg}$ & 12 & $\% 10,8$ & 18 & $\% 18,2$ \\
\hline & $2 \mathrm{~kg}$ ve üstü & 11 & $\% 9,9$ & 10 & $\% 10,1$ \\
\hline \multirow[t]{4}{*}{ Pil } & 500 gr ve daha az & 74 & $\% 66,7$ & 25 & $\% 25,3$ \\
\hline & 500 gr- 1 kg & 27 & $\% 24,3$ & 42 & $\% 42,4$ \\
\hline & $1 \mathrm{~kg}-2 \mathrm{~kg}$ & 8 & $\% 7,2$ & 17 & $\% 17.1$ \\
\hline & $2 \mathrm{~kg}$ ve üstü & 2 & $\% 1,8$ & 15 & $\% 15,2$ \\
\hline \multirow[t]{4}{*}{ Yağ } & 500 gr ve daha az & 55 & $\% 49,5$ & 55 & $\% 55,6$ \\
\hline & 500 gr- $1 \mathrm{~kg}$ & 32 & $\% 28,8$ & 18 & $\% 18,1$ \\
\hline & $1 \mathrm{~kg}-2 \mathrm{~kg}$ & 17 & $\% 15,3$ & 16 & $\% 1,2$ \\
\hline & $2 \mathrm{~kg}$ ve üstü & 7 & $\% 6,4$ & 10 & $\% 10.1$ \\
\hline
\end{tabular}

Tablo 12 incelendiğinde, günlük evden çıkan atık miktarının bireylerin çalışma durumuna göre farklılık gösterip göstermediğine ait verilere ulaşılmaktadır. Ulaşılan verilere göre günlük evden çıkan atık miktarının, bireylerin çalışma durumlarından etkilendiği sonucuna ulaşılmaktadır.

Bireylerin atıklarn ayrnştırılması ve atıklarn geri dönüşümüyle ilgili tutumlarnnı bireylerin aile üyesi sayılarnna göre farklılı göstermesine ilişkin bulgular

Bireylerin aile üyesi sayılarının atıkların dönüşümünde ve çevreye karşı duyarlılıklarında etkin rol oynayıp oynamadığına dair yapılan araştırmanın sonuçları Tablo 13'te yer verilmiştir. Bu tabloya göre aile üye sayısı 2 veya daha az olan bireylerin, atıkların geri dönüştürülmesi sorularına daha olumlu yanıtlar verdiği gözlemlenmektedir. Çevreye karşı duyarlılık derecelerine bakıldığında yine aile üye sayısı 2 veya daha az olan bireylerin diğer bireylere oranla daha fazla duyarlı oldukları tespit edilmektedir. 
Tablo 13. Bireylerin Aile Üyesi Sayılarnna Göre Çevre Bilincinin Değerlendirilmesi

\begin{tabular}{|c|c|c|c|c|c|c|c|c|c|}
\hline \multirow[t]{2}{*}{ Değişkenler } & & \multicolumn{2}{|c|}{2 veya daha az } & \multicolumn{2}{|l|}{ 3-4 } & \multicolumn{2}{|c|}{$5-7$} & \multicolumn{2}{|c|}{8 ve daha fazla } \\
\hline & & $\mathbf{N}$ & $\%$ & $\mathbf{N}$ & $\%$ & $\mathbf{N}$ & $\%$ & $\mathbf{N}$ & $\%$ \\
\hline \multirow{2}{*}{$\begin{array}{l}\text { Atıkların geri dönüştürül- } \\
\text { mesine katkısı }\end{array}$} & Olumlu & 30 & $\% 75$ & 62 & $\% 69.7$ & 48 & $\% 70.6$ & 6 & $\% 46.2$ \\
\hline & Olumsuz & 10 & $\% 25$ & 27 & $\% 30.3$ & 20 & $\% 29.4$ & 7 & $\% 53.8$ \\
\hline \multirow{5}{*}{$\begin{array}{l}\text { En çok geri dönüşümü ya- } \\
\text { pilabilen madde }\end{array}$} & Kağıt & 20 & $\% 50$ & 30 & $\% 33.7$ & 17 & $\% 25$ & 4 & $\% 30.7$ \\
\hline & Cam & 4 & $\% 10$ & 18 & $\% 20.2$ & 5 & $\% 7.4$ & 2 & $\% 15.4$ \\
\hline & Plastik & 7 & $\% 17.5$ & 14 & $\% 15.7$ & 9 & $\% 13.2$ & 1 & $\% 7.7$ \\
\hline & Pil & 5 & $\% 12.5$ & 21 & $\% 23.6$ & 20 & $\% 29.4$ & 5 & $\% 38.5$ \\
\hline & Yağ & 4 & $\% 10$ & 6 & $\% 6.8$ & 17 & $\% 25$ & 1 & $\% 7.7$ \\
\hline \multirow[t]{2}{*}{ Çevreye karşı duyarlılığı } & Olumlu & 27 & $\% 67.5$ & 52 & $\% 58.4$ & 35 & $\% 51.5$ & 5 & $\% 38.5$ \\
\hline & Olumsuz & 13 & $\% 32.5$ & 37 & $\% 41.6$ & 33 & $\% 48.5$ & 8 & $\% 61.5$ \\
\hline
\end{tabular}

Tablo 14. Bireylerin Aile Üyeleri Sayısına Göre Günlük Evlerden Çıkan Atık Miktarı

\begin{tabular}{|c|c|c|c|c|c|c|c|c|c|}
\hline \multicolumn{2}{|c|}{ Günlük Evlerden Çıkan Atık Miktarı } & \multicolumn{2}{|c|}{2 veya daha az } & \multicolumn{2}{|l|}{ 3-4 } & \multicolumn{2}{|l|}{$5-7$} & \multicolumn{2}{|c|}{8 ve daha fazla } \\
\hline & & $\mathbf{N}$ & $\%$ & $\mathbf{N}$ & $\%$ & $\mathbf{N}$ & $\%$ & $\mathbf{N}$ & $\%$ \\
\hline \multirow[t]{4}{*}{ Kağıt } & 500 gr ve daha az & 25 & 62.5 & 32 & $\% 35,9$ & 25 & 36,8 & 2 & $\% 15,4$ \\
\hline & 500 gr- $1 \mathrm{~kg}$ & 10 & 25 & 28 & $\% 31,5$ & 30 & 44,1 & 5 & $\% 38,5$ \\
\hline & $1 \mathrm{~kg}-2 \mathrm{~kg}$ & 3 & 7,5 & 18 & $\% 20.2$ & 7 & 10,2 & 4 & $\% 30,8$ \\
\hline & $2 \mathrm{~kg}$ ve üstü & 2 & 5 & 11 & $\% 12,4$ & 6 & 8,9 & 2 & $\% 15,3$ \\
\hline \multirow[t]{4}{*}{ Cam } & 500 gr ve daha az & 30 & 75 & 42 & $\% 47,2$ & 22 & 32,4 & 1 & $\% 7.7$ \\
\hline & 500 gr- $1 \mathrm{~kg}$ & 7 & 17,5 & 31 & $\% 34,8$ & 35 & 51,5 & 7 & $\% 53,8$ \\
\hline & $1 \mathrm{~kg}-2 \mathrm{~kg}$ & 3 & 7,5 & 10 & $\% 11,2$ & 6 & 8,9 & 3 & $\% 23,1$ \\
\hline & $2 \mathrm{~kg}$ ve üstü & - & & 6 & $\% 6,8$ & 5 & 7,2 & 2 & $\% 15,4$ \\
\hline \multirow[t]{4}{*}{ Plastik } & 500 gr ve daha az & 22 & 55 & 54 & $\% 60,7$ & 18 & 26,5 & 1 & $\% 7,7$ \\
\hline & 500 gr- $1 \mathrm{~kg}$ & 9 & 22,5 & 20 & $\% 22,5$ & 35 & 51,5 & 6 & $\% 46,1$ \\
\hline & $1 \mathrm{~kg}-2 \mathrm{~kg}$ & 5 & 12,5 & 9 & $\% 10$ & 10 & 14,7 & 4 & $\% 30,8$ \\
\hline & 2kg ve üstü & 4 & 10 & 6 & $\% 6,8$ & 5 & 7.3 & 2 & $\% 15,4$ \\
\hline \multirow[t]{4}{*}{ Pil } & 500 gr ve daha az & 20 & 50 & 40 & $\% 44,9$ & 25 & 36,8 & 2 & $\% 15,4$ \\
\hline & 500 gr- $1 \mathrm{~kg}$ & 10 & 25 & 42 & $\% 47,2$ & 30 & 44,1 & 8 & $\% 61,5$ \\
\hline & $1 \mathrm{~kg}-2 \mathrm{~kg}$ & 8 & 20 & 5 & $\% 5,6$ & 9 & 13,2 & 2 & $\% 15,4$ \\
\hline & $2 \mathrm{~kg}$ ve üstü & 2 & 2 & 2 & $\% 2,3$ & 4 & 5,9 & 1 & $\% 7,7$ \\
\hline \multirow[t]{4}{*}{ Yağ } & 500 gr ve daha az & 33 & 82,5 & 47 & $\% 52,8$ & 35 & 51,5 & 3 & $\% 23,1$ \\
\hline & 500 gr- $1 \mathrm{~kg}$ & 5 & 12,5 & 30 & $\% 33,8$ & 27 & 39,8 & 7 & $\% 53,8$ \\
\hline & $1 \mathrm{~kg}-2 \mathrm{~kg}$ & 2 & 5 & 8 & $\% 8,9$ & 5 & 7,3 & 1 & $\% 7,8$ \\
\hline & $2 \mathrm{~kg}$ ve üstü & - & & 4 & $\% 4,5$ & 1 & 1,4 & 2 & $\% 14,4$ \\
\hline
\end{tabular}

Tablo 14'e göre günlük evden çıkan atık miktarının, bireylerin aile üyeleri sayısına göre değişip değişmediği bulgusuna yer verilmiştir. Ulaşılan verilere göre günlük evden çıan atık miktarı bireylerin aile üyeleri sayısı faktörüne göre değişiklik göstermektedir. 


\section{Sonuç ve Öneriler}

Araştırmanın ilk bulgusu incelendiğinde, bireylerin atıkların ayrıştırılması ve atıkların geri dönüşümüyle ilgili tutumlarının, bireylerin cinsiyetlerine göre farklılık gösterdiği ortaya çıkmıştır. Bu bulguda, kadınların erkeklere oranla \%6.4 gibi bir oranla atıkların ayrıştırılarak dönüştürülmesinde daha etkin rol oynadığı görülmektedir. Bu durumu kadınların kişilik olarak daha titiz daha düzenli ve dikkatli olması açısından erkeklere göre daha etkili olduğu şeklinde yorumlayabiliriz. Yine aynı bulguda, kadınların daha çok kağıt atıklarında geri dönüşüm yaptıkları, erkeklerin ise en çok kağıt ve pil atıklarında geri dönüşüm yaptı̆̆ı sonucuna ulaşılabilmektedir. Örneklem grubuna geri dönüşüme katkılarının olup olmadığını belirlenmesine ilişkin sorularda, kadinlar erkeklere oranla \%8.2 oraninda daha fazla olumlu yanit vererek, kadınların erkeklerden daha fazla çevreye karşı duyarlı oldukları gözlemlenmektedir. Diğer bir bulguya göre günlük evden çıan atık miktarının, bireylerin cinsiyetine göre değişiklik gösterdiği sonucuna ulaşılmaktadır.

Araştırmanın ikinci bulgusunda, bireylerin atıkların ayrıştırılması ve atıkların geri dönüşümüyle ilgili tutumlarının, bireylerin yaş bilgilerine göre farklılık gösterdiği görülmektedir. Bu bulguya göre yaş gruplarının atıkların geri dönüştürülerek tekrar kullanılmasını sağlanmaya yönelik sorulan sorulara 17 ve altı yaş grubunun olumlu katkısı \%20, 18-25 yaş grubunun olumlu katkısı \%26,3, 26-35 yaş grubunun olumlu katkısı \%32,9, 36-45 yaş grubunun olumlu katkısı $\% 57,7,46-59$ yaş grubunun olumlu katkısı $\% 40$ ve son olarak 60 yaş ve üstü grubun olumlu katkısı \%25 olarak görülmektedir. Ayrıştırılarak geri dönüşümü sağlanan maddelerde, kağıt atıklarının tüm yaş gruplarınca ilk sırada önem verilerek ayrıştırıldığı gözlenmektedir. Geri dönüşüme katkıları ve çevre bilincine duyarlılık oranlarına bakıldığında, 36-45 yaş grubunun diğer yaş gruplarına oranla daha duyarlı olduğu yönünde soruların cevaplandığı görülmektedir. Bu bulguya göre atıkların yeniden kazandırılması, geri dönüşüm, çevre bilinci gibi kavramların daha küçük yaşlardan öğretilerek her yaş grubuna farklı şekilde eğitiminin verilmesinin gerekliliği yorumuna ulaşılabilir.

Araştırmanın üçüncü bulgusunda, evli bireylerin bekar bireylere göre \%3.2 oranında daha fazla atıkları ayrıştırdıkları görülmektedir. Her iki örneklem grubunun da, kağıt atıklarını daha fazla ayrıştırarak atıkların geri dönüş- 
türülmesine katkık sağladıkları bilgisine ulaşılmaktadır. Evli bireylerin çevreye karşı duyarlılık sorularına olumlu cevap verirken, bekar bireylerin olumsuz cevap verdiği saptanmaktadır. Bir diğer veri analizine bakıldığında, bireylerin medeni durumlarının evlerden çıkan günlük atık miktarını etkilediğine ulaşılmaktadır.

Araştırmanın dördüncü bulgusunda, eğitim düzeylerinin atıkların dönüştürülmesinde ve bireylerin çevre bilincinin gelişmesinde farklılık gösterdiği bulgusuna ulaşılabilir. İlkokul ve lise düzeyinde eğitim gören kişilerin, atıkların dönüştürülmesine olumlu bir etkisinin olmadığı görülürken, üniversite ve lisansüstü düzeyinde eğitim görmüş bireylerin olumlu bir katkısı olduğu görülmektedir. Her bir örneklem grubunun, en çok kağıt atıkların ayrıştırılmasında etkin rol oynadığı bulgusuna ulaşılabilir. İlkokul düzeyinde eğitim gören grubun çevreye karşı duyarlılı̆̆ının olumlu olmadığı, diğer grupların ise daha olumlu yaklaştı̆̆ı anlaşılmaktadır. Günlük evlerden çıkan atık miktarının verilerinin yer aldığı tablo incelenecek olursa, bireylerin eğitim düzeylerinin evlerden çıan günlük atık miktarını etkilediği tespit edilmektedir.

Araştırmanın beşinci bulgusunda, çalışan kişilerin çalışmayan kişilere göre \%0,4 oranında atıkların dönüştürülmesinde daha etkin rol oynadıkları görülmektedir. Çalışan bireylerin cam atıklarını ilk sırada ayrıştırarak geri dönüşüme kazandırdığı bulgusuna ulaşılırken, çalışmayan bireylerin ise kağıt atıklarını ilk sırada ayrıştırdıklarına bulgusuna ulaşılmaktadır. Günlük evlerden çıkan atık miktarı verilerine göre ise atık miktarları bireylerin çalışıp çalışmadıklarından etkilendiği sonucuna ulaşılmaktadır.

Araştırmanın son ve altıncı bulgusunda ise çalışma grubunun aile üyeleri sayısındaki değişikliğin, atıkların dönüştürülmesinde ve çevreye karşı oluşan duyarlılıkta farklılık oluşturduğu tespit edilmiştir. Atıkların geri dönüştürülmesine katkısına aile üye sayısı 2 veya daha az kişiden oluşanların \%75, 3-4 kişiden oluşanların \%69, 5-7 kişiden oluşanların \%71, 8 ve daha fazla kişiden oluşanların \%46 oranında olumlu cevap verdikleri görülmüştür. Her örneklem grubunun da diğer maddelere oranla, kağıt atıklara daha fazla önem vererek ayrıştırıp geri dönüşüme kazandırdıkları tespit edilmiştir. Aile birey sayısı 2 veya daha az olan grubun çevreye karşı diğer gruplara oranla daha duyarlı olduğu görülmüştür.

Atıkların oluşturduğu zararları en az düzeye indirmek ve geri dönüşümünü sağlamak amacıyla bazı tedbirler alınabilir. Evlerde çıkan kağıt, cam 
ve plastik gibi geri dönüştürülebilen maddelerin atıkları geçici bir süre biriktirilebilir ve daha sonra belediyenin belirlediği toplama alanlarına bırakılabilir, bağlı bulunan belediye ile iletişime geçilerek toplanılması istenebilir. Atıkların oluşturduğu zararları ve bu zararların yol açtığı sorunları, çevre bilinci oluşturarak, sadece mevcut çözümlerle kalmayıp geleceğe dönük, atık planları ve projeleri oluşturularak uygulamaya geçirilebilir. Çevre bilincinin yaygınlaştırılması için çevre kuruluşları çoğaltılmalı ve okullarda çevre bilincini içeren dersler verilmelidir. Ortaya çıkan atıkların geri dönüşümü için tesislerin sayıları arttırılabilir ve bu tesisler bireylerin kolaylıkla ulaşabilecekleri alanlara, atık kutuları yerleştirilerek geri dönüşüm verimliliği sağlanılabilir.

Çalışma, Karaman ilinde belli sayıda yapılmasından dolayı genelleme yapılamaması ve diğer iller ile kıyas yapılamaması çalışmanın kısıtlılıkları arasında yer almaktadır. Çevreye karşı tutumları etkileyen birçok davranış olması ve bu davranışların tamamının, bu çalışma içinde yer almaması elde edilen bilgileri sınırlamaktadır. Kullanılan yöntem gereği, kişilerin öznel düşünceleri alınmış ve bilgiler bu çerçevede değerlendirilmiştir. Bu nedenle, bilgilerin ve elde edilen bulguların doğruluğu göreceli olmasıda çalışmanın diğer kısıtlarını oluşturmaktadır.

Bu çalışmanın, daha sonra yapılacak olan akademik çalışmalara kaynak niteliği taşıyarak fayda sağlayacağı öngörülmektedir. 


\title{
EXTENDED ABSTRACT
}

\section{Recycling Awareness in Domestic Waste and Investigation of Its Contribution to the Economy}

\author{
Ahmet Alper Sayın - Asli Yerli \\ Karamanoğlu Mehmetbey University
}

With the increasing population of the world, the problems caused by waste have become one of the major environmental problems in recent times. With the increasing population, the issue of recycling of end-of-life wastes in the globalizing world is increasing day by day due to the desire to minimize the harmful effects of wastes on the environment and economy. As a result of this increasing interest, businesses and governments pay attention to recycling activities of waste and invest in an efficient and profitable economic transformation in the long run. Nowadays, the situation of the wastes that we encounter with each passing day creates serious problems for countries. As a result, targets are set by seeking methods to prevent waste of raw materials, recycle waste, and cope with potential energy problems. As a result of the economic and environmental deterioration that occur with the increase of waste and the constantly developing consumption habits, the problems of rapid depletion of raw materials play an inevitable role in the increase of the importance given to reverse logistics.

The purpose of this research is to measure the household's awareness of household waste, which has an important place today, and to reveal the environmental impact of waste and its contribution to the economy. Information on waste and environmental sensitivity of household members was collected through the questionnaire prepared. The study was carried out by oneto-one interviews and phone calls. The study group of the research consists of 210 household members, 124 of whom are women and 86 of which are men, in the center of Karaman. The questionnaire was prepared by taking inspiration from previous studies and taking the opinions of the academicians working on the subject. Individuals selected in the study were randomly determined from different households. Necessary permissions were obtained from individuals to conduct the survey. The purpose of the research was exp- 
lained to the individuals and information was given by explaining the questions that were not understood in the form. The survey application was implemented in Karaman between September and December 2019.

When the first finding of the study is examined, it is seen that women play a more active role in the separation and recycling of wastes with a rate of $6.4 \%$ compared to men. Again, in the same finding, it can be concluded that women recycle mostly paper waste, while men recycle mostly paper and battery wastes. It is observed that women are more environmentally sensitive than men, responding to the sample group with a positive response rate of $8.2 \%$ more than men to questions about whether they contribute to recycling. According to another finding, it is concluded that the daily amount of waste from the house varies according to the gender of the individuals.

In the second finding of the study, the questions asked by age groups to ensure the reuse of wastes by recycling; the positive contribution of the age group 17 and under is $20 \%$, the positive contribution of the $18-25$ age group is $26 \%$, the positive contribution of the $26-35$ age group is $33 \%$, the positive contribution of the $36-45$ age group is $58 \%$, the positive contribution of the $46-$ 59 age group is $40 \%$ and the positive contribution of the group aged 60 and over was determined as $25 \%$. In the materials that are separated and recycled; it is observed that paper wastes are sorted out by all age groups with the highest priority. Considering their contribution to recycling and environmental awareness, it is seen that the questions are answered that the 36-45 age group is more sensitive than other age groups. According to this finding; it can be interpreted that concepts such as recycling of waste, recycling, environmental awareness should be taught from younger ages and education should be given differently to each age group.

In the third finding of the research; It is determined that while married individuals give positive answers to environmental sensitivity questions, single individuals give negative answers. Looking at another data analysis, it is found that the marital status of the individuals affects the daily amount of waste from homes.

In the fourth finding of the study, it can be found that education levels differ in recycling of waste and in the development of environmental awareness of individuals. While it has been observed that people studying at primary and high school level do not have a positive effect on the recycling of 
waste, it is seen that individuals who have education at university and graduate level have a positive contribution. It can be found that each sample group plays an active role in the separation of paper waste. It is understood that the group studying at the primary school level is not sensitive to the environment, and the other groups have a more positive approach.

In the fifth finding of the study, it is found that working individuals separate glass waste in the first place and recycle it, while non-working individuals separate paper waste first. According to the data on the amount of waste from daily homes, it is concluded that the amount of waste is affected by whether individuals work or not.

In the last and sixth findings of the study, it was determined that the change in the number of family members of the study group caused a difference in the recycling of waste and the sensitivity to the environment. It has been determined that each sample group gives more importance to paper wastes than other materials, separating them and recycling them. It has been observed that the group with 2 or less family members is more sensitive to the environment than the other groups.

As a result, some measures can be taken to minimize the damages caused by wastes and to ensure their recycling. The wastes of recyclable materials such as paper, glass and plastic from the houses can be collected temporarily and then left to the collection areas designated by the municipality, contacting the municipality affiliated with it and requesting their collection. The damages caused by the wastes and the problems caused by these damages; By creating environmental awareness, not only existing solutions but also future waste plans and projects can be created and implemented. Environmental organizations should be increased in order to popularize environmental awareness and lectures including environmental awareness should be given in schools. The number of facilities can be increased for the recycling of the resulting waste and recycling efficiency can be achieved by placing waste bins in areas where these facilities can be easily reached by individuals.

\section{Kaynakça / References}

Aydın, N. (2007). Katı atık yönetiminde optimal planlama için bulanık doğrusal programlama yaklaşımı. Yayımlanmamış Yüksek Lisans Tezi. Yıldız Teknik Üniversitesi Fen Bilimleri Enstitüsü, İstanbul. 
Coşkun, A. (2011). Üreticilerin tersine lojistik faaliyetlerini etkileyen faktörler: beyaz eşya sektöründe bir uygulama. Basılmamış Yüksek Lisans Tezi, Sosyal Bilimler Enstitüsü, Nevşehir Üniversitesi.

Demirel, N. Ö., ve Gökçen, H. (2008). Geri kazanımlı imalat sistemleri için lojistik ağı tasarımı: literatür araştırması. Gazi Üniversitesi Mühendislik-Mimarlı Fakültesi Dergisi, 23(4).

Eurostat (2018). Environment - overviev. 10 Ekim 2019 tarihinde https://ec.europa.eu/eurostat/web/lucas/data/primary-data/2018 adresinden erişilmiştir.

Fleischmann, M., Bloemhof-Ruwaard, J. M., Dekker, R., Van der Laan, E., Van Nunen, J. A., ve Van Wassenhove, L. N. (1997). Quantitative models for reverse logistics: A review. European journal of operational research, 103(1), 1-17.

İrak, G., ve Kurt, İ. (2019). Tersine lojistik maliyetlerinin hesaplanmasında faaliyet tabanlı maliyetleme yöntemi kauçuk işletmesi örneği. Muhasebe bilim dünyasi, 21(2), 374-392.

Karaçay, G. (2005). Tersine lojistik: kavram ve işleyiş. Çukurova Üniversitesi Sosyal Bilimler Enstitüsü Dergisi, 14(1), 317-332

Nakiboğlu, G. (2007). Tersine lojistik: önemi ve dünyadaki uygulamaları. Gazi Üniversitesi İktisadi ve İdari Bilimler Fakültesi Dergisi, 9(2), 181-196.

Solak, S. G., ve Pekküçükşen, S. (2018). Türkiye'de kentsel katı atık yönetimi: karşılaştırmalı bir analiz. MANAS Sosyal Araştırmalar Dergisi, 7(3).

Şengül, Ü. (2011). Tersine lojistik kavramı ve tersine lojistik ağ tasarımı, Atatürk Üniversitesi İktisadi İdari Bilimler Dergisi. Atatürk Üniversitesi İktisadi ve İdari Bilimler Fakültesi Dergesi, 25, 407-429.

Tekin, M., ve Sayın, A. A. (2017). Lojistik faaliyetlerde satınalma faaliyetinde karşılaşılan riskler ve perakende sektöründe uygulaması. Kesit Akademi, 10, 545-569.

TC. Çevre ve Şehircilik Bakanlığı (2019). Ulusal atık yönetimi ve eylem planı (2023). 12 Ekim 2019 tarihinde https://csb.gov.tr/ adresinden erişilmiştir.

The World Bank (2019). Solid waste management. 7 Ekim 2019 tarihinde https://www.worldbank.org/ adresinden erişilmiştir.

Türkiye İstatistik Kurumu (2018). Belediye atık istatistikleri. (Yayın No: 30666). 5 Ekim 2019 tarihinde http://www.tuik.gov.tr adresinden erişilmiştir.

\section{Kaynakça Bilgisi / Citation Information}

Sayın, A. A. ve Yerli, A. (2020). Evsel atıklarda geri dönüşüm farkındalı̆̆ı ve ekonomiye katkısının incelenmesi. OPUS-Uluslararası Toplum Araştırmaları Dergisi, 16(29), 1849-1874. DOI: 10.26466/opus.689183 